Conflict of interest: KCH serves as scientific advisor to Provention Bio, Semma, Forkhead, and Bristol Myers Squibb. PAG serves as a consultant to Bristol Myers Squibb, Lilly, Kamada, Tolerion, and Viacyte and is cofounder and shareholder of IM Therapeutics. SEG served on advisory boards for Tolerion, Caladrius, and Immunomolecular Therapeutics and led a DSMB for Novo Nordisk. CW, TJ, CU, XW, SP, BG, and PDG are employees of Pfizer Inc. and may own stock/options in the company. ML, SLB, and MS were employees of Pfizer Inc. at the time of this research. JHP serves as a consultant for Insulet, Mannkind, Novo Nordisk, and Sanofi. JBM serves as a consultant for Boehringer Ingelheim, NovoNordisk, Bayer, and Aegerion and is a speaker for Aegerion, Dexcom, Janssen, and Mannkind. Grants to Washington University include Dexcom, AstraZeneca, Mannkind, and Novartis as sponsors.

Copyright: (c) 2019, American Society for Clinical Investigation.

Submitted: April 12, 2019

Accepted: October 29, 2019

Published: December 19, 2019

Reference information: JCI Insight.

2019;4(23):e126054.

https://doi.org/10.1172/jci.

insight.126054.

\section{Immunomodulatory activity of humanized anti-IL-7R monoclonal antibody RN168 in subjects with type 1 diabetes}

Kevan C. Herold, ${ }^{1,2}$ Samantha L. Bucktrout, ${ }^{3}$ Xiao Wang, ${ }^{3}$ Bruce W. Bode, ${ }^{4}$ Stephen E. Gitelman,, 5 Peter A. Gottlieb, ${ }^{7,8,9}$ Jing Hughes, ${ }^{10}$ Tenshang Joh, ${ }^{11}$ Janet B. McGill, ${ }^{10}$ Jeremy H. Pettus, ${ }^{12}$ Shobha Potluri, ${ }^{3}$ Desmond Schatz, ${ }^{13}$ Megan Shannon, ${ }^{11}$ Chandrasekhar Udata, ${ }^{11}$ Gilbert Wong, ${ }^{3}$ Matteo Levisetti, ${ }^{3}$ Bishu J. Ganguly, ${ }^{3}$ Pamela D. Garzone, ${ }^{3}$ and the RN168 Working Group ${ }^{14}$

'Department of Immunobiology and 'Department of Internal Medicine, Yale School of Medicine, New Haven, Connecticut, USA. ${ }^{3}$ Rinat, Pfizer Inc., South San Francisco, California, USA. ${ }^{4}$ Atlanta Diabetes Associates Research, Atlanta, Georgia, USA. ${ }^{5}$ Department of Pediatrics and ${ }^{6}$ Diabetes Center, UCSF, San Francisco, California, USA. ${ }^{7}$ Department of Pediatrics, ${ }^{8}$ Department of Medicine, and ${ }^{9}$ Barbara Davis Diabetes Center, University of Colorado School of Medicine Anschutz Medical Campus, Anschutz, Colorado, USA. ${ }^{10}$ Division of Endocrinology, Metabolism and Lipid Research, John T. Milliken Department of Internal Medicine, Washington University School of Medicine in Saint Louis, Saint Louis, Missouri, USA ${ }^{11}$ Worldwide R\&D, Pfizer Inc., San Diego, California, USA. ${ }^{2}$ Department of Medicine, VA San Diego Healthcare System, San Diego, California, USA. ${ }^{13}$ Department of Pediatrics, College of Medicine, University of Florida, Gainesville, Florida, USA. ${ }^{14}$ RN168 Working Group is detailed in the Supplemental Acknowledgments.

BACKGROUND. The cytokine IL-7 is critical for T cell development and function. We performed a Phase Ib study in patients with type 1 diabetes (T1D) to evaluate how blockade of IL-7 would affect immune cells and relevant clinical responses.

METHODS. Thirty-seven subjects with T1D received s.c. RN168, a monoclonal antibody that blocks the IL -7 receptor $\alpha$ (IL7R $\alpha$ ) in a dose-escalating study.

RESULTS. Between $90 \%$ and $100 \%$ IL-7R occupancy and near-complete inhibition of pSTAT5 was observed at doses of RN168 $1 \mathrm{mg} / \mathrm{kg}$ every other week (Q2wk) and greater. There was a significant decline in $\mathrm{CD}^{+}$and $\mathrm{CD} 8^{+}$effector and central memory $\mathrm{T}$ cells and $\mathrm{CD4} 4^{+}$naive cells, but there were fewer effects on $\mathrm{CD}^{+}$naive T cells. The ratios of Tregs to $\mathrm{CD4}{ }^{+}$or $\mathrm{CD8} 8^{+}$effector and central memory T cells versus baseline were increased. RNA sequencing analysis showed downmodulation of genes associated with activation, survival, and differentiation of T cells. Expression of the antiapoptotic protein $\mathrm{Bcl}-2$ was reduced. The majority of treatment-emergent adverse events (TEAEs) were mild and not treatment related. Four subjects became anti-EBV IgG ${ }^{+}$after RN168, and 2 had symptoms of active infection. The immunologic response to tetanus toxoid was preserved at doses of 1 and 3 $\mathrm{mg} / \mathrm{kg}$ Q2wk but reduced at higher doses.

CONCLUSIONS. This trial shows that, at dosages of 1-3 mg/kg, RN168 selectively inhibits the survival and activity of memory $T$ cells while preserving naive $T$ cells and Tregs. These immunologic effects may serve to eliminate pathologic T cells in autoimmune diseases.

TRIAL REGISTRATION. NCT02038764.

FUNDING. Pfizer Inc.

\section{Introduction}

The cytokine IL-7 is required for the development of T cells and lymphoid structures and is needed to maintain their survival and immune homeostasis (1). In particular, IL-7 is responsible for the longevity of $\mathrm{CD}^{+}$and $\mathrm{CD}^{+}$central and effector memory $\mathrm{T}$ cells (2-6). IL-7-mediated $\mathrm{T}$ cell survival signaling occurs primarily via the Jak/Stat pathway and, to a lesser extent, the PI3K pathway $(7,8)$. Resting naive $\mathrm{T}$ cells express high levels of IL-7 receptor $\alpha$ (IL-7RA), which is rapidly downregulated once these cells are exposed 
to antigen and become effector cells. Subsequent removal of antigen restores IL-7RA expression on T cells destined to become memory cells (9). IL-7RA blockade may arrest or reverse autoimmunity by attenuating these survival signals and depleting memory $\mathrm{T}$ cells, while leaving functional Tregs intact $(10,11)$.

Reduced expression of IL-7RA has been seen in conditions of chronic CD8 $8^{+} \mathrm{T}$ cell activation that occurs with autoimmunity, with chronic viral infections, and in the tumor microenvironment, and it is associated with functional T cell "exhaustion" (12-14). Exhausted T cells do not produce cytokines such as IFN- $\gamma$ and IL-2, which are needed for T cell effector function $(15,16)$. In addition to reduced expression of IL-7RA, exhausted $\mathrm{T}$ cells show an increased expression of inhibitory receptors such as programmed cell death-1 (PD-1) and lymphocyte activation gene-3 $(L A G 3)(13,15,17)$. Increased production of the soluble form of IL-7RA via alternative splicing is associated with increased multiple sclerosis risk (18), suggesting a role for IL-7RA in shared mechanisms of autoimmunity. Indeed, improved prognoses were associated with reduced expression of IL-7RA in patients with systemic lupus erythematosus, type 1 diabetes (T1D), antineutrophil cytoplasmic antibody vasculitis, and idiopathic pulmonary fibrosis (14).

Because of the central role of IL-7RA in T cell survival and function, strategies that exploit this pathway to induce anergy, exhaustion, or apoptosis of pathogenic T cells may have therapeutic utility in autoimmune conditions. IL-7RA blockade may facilitate induction of anergy or exhaustion by upregulating PD-1 (10) or promoting apoptosis of autoantigen reactive $\mathrm{T}$ cells by downregulating anti-apoptotic $\mathrm{B}$ cell leukemia-2 (Bcl-2) molecules (e.g., Bcl-2, myeloid cell leukemia-1) $(7,8)$ and by triggering transcriptional induction of the proapoptotic Bcl-2 family member Bcl-2-interacting mediator of cell death (19). In the nonobese diabetic (NOD) mouse model of T1D, IL-7RA blockade was shown to spare Tregs (10), which is consistent with their low expression of IL-7RA.

In $\mathrm{T} 1 \mathrm{D}$, clinical and preclinical studies have suggested that the pathogenic $\beta$ cell destruction is mediated by $\mathrm{T}$ cells, and preclinical studies have shown that the activity of diabetogenic $\mathrm{T}$ cells is dependent on IL-7. In NOD mice, a preclinical model, IL-7R blocking antibodies reduced CD4 ${ }^{+} \mathrm{T}$ cell infiltration in the pancreas but spared Tregs, consistent with their low levels of expression of IL-7RA. There was increased expression of PD-1 and other inhibitory signal receptors on effector T cells, leading to prevention and reversal of diabetes $(10,11,20)$. In addition, observations from $T$ cell-directed immune therapies suggest a central role of IL-7R signaling in the efficacy of these agents. A recent study of an LFA-3-Fc fusion protein, alefacept, as well as an FCR nonbinding anti-CD3 mAb, teplizumab, showed improved C-peptide responses for 2 years when patients with new-onset T1D were treated (21-23). There was decreased expression of IL-7R on $\mathrm{CD}^{+}$central memory $\mathrm{T}$ cells in the teplizumab-treated responders $(24,25)$. With alefacept, this is consistent with the increased expression of IL-7R by CD2 signaling.

RN168 (PF-06342674), a humanized IgG1 monoclonal antibody (mAb), binds the human IL-7RA (CD127) to block IL-7-mediated signaling. Because of the demonstrated role of $\mathrm{T}$ cells and the efficacy of RN168 in preclinical models, we conducted a multiple-ascending dose phase Ib trial of RN168 in adult subjects with T1D to determine the safety and immunologic effects of RN168 $(26,27)$. Herein, we describe the effects of the drug treatment on $\mathrm{T}$ cell subsets, as well as the safety, tolerability, immunogenicity, and pharmacokinetics $(\mathrm{PK})$ of drug treatment.

\section{Results}

Study population. A total of 37 subjects were randomly assigned to dose-ascending treatment with RN168 1 $\mathrm{mg} / \mathrm{kg}$ every other week (Q2wk) $\times 6$ doses, $3 \mathrm{mg} / \mathrm{kg}$ Q2wk $\times 6$ doses, $8 \mathrm{mg} / \mathrm{kg}$ Q2wk $\times 6$ doses, $6 \mathrm{mg} / \mathrm{kg}$ every week $(\mathrm{QW}) \times 12$ doses, or placebo in a double-blinded, placebo controlled (within each) cohort manner. Thirty-seven subjects were evaluated for pharmacodynamics (PD) and safety outcomes; there were 8, 9, 8, and 5 subjects in the 4 RN168 dosing groups, respectively, and 7 in the placebo group. A total of 4 subjects discontinued before completion of the study (Figure 1). One subject receiving $3 \mathrm{mg} / \mathrm{kg}$ was discontinued due to a serious adverse event of atrial fibrillation deemed unrelated to treatment. One subject in the $6 \mathrm{mg} / \mathrm{kg} \mathrm{QW}$ group did not receive all doses of study drug due to active Epstein-Barr virus (EBV) infection. Demographic characteristics of the study population are shown in Supplemental Table 1 (supplemental material available online with this article; https://doi.org/10.1172/jci.insight.126054DS1).

$P D$ and $P K$ results. An analysis of the serum levels of RN168 are shown in Supplemental Figure 1 and Supplemental Table 2. Exposure, based on area under the curve $\left(\mathrm{AUC}_{\tau}\right)$ and peak concentration $\left(\mathrm{C}_{\max }\right)$, increased in a greater-than dose-proportional manner after multiple doses. Across all doses, and for single and multiple doses, absorption was slow (time to maximal concentration [ $\mathrm{T}_{\max }$ ] 48.9-86.3 hours), as was 


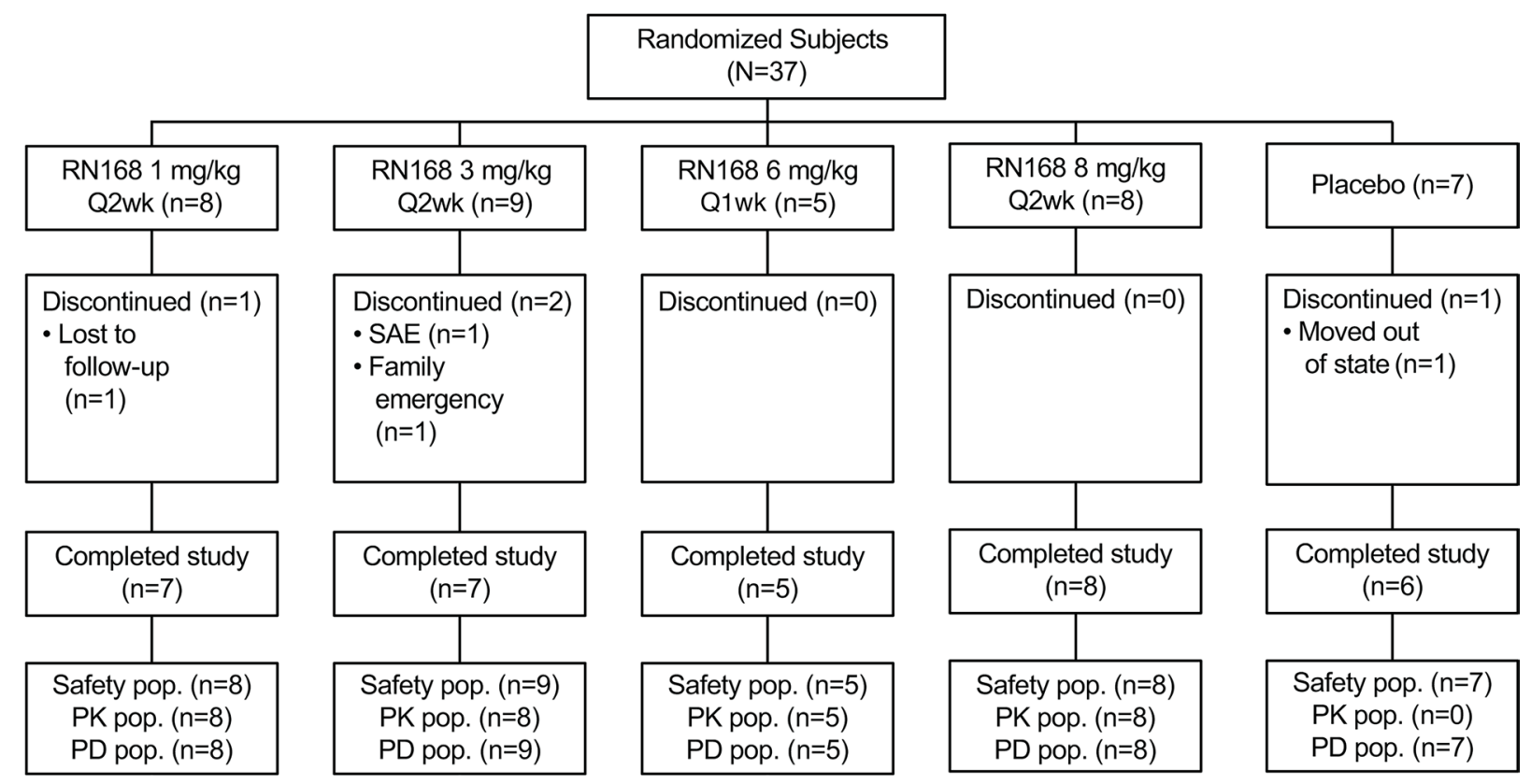

Figure 1. Subject disposition. PK, pharmacokinetics; PD, pharmacodynamics; SAE, serious adverse event.

elimination (half-life $\left[\mathrm{T}_{1 / 2}\right]$ was 64.6 hours with RN168 $3 \mathrm{mg} / \mathrm{kg}$ Q2wk, and 85.5 hour with RN168 $8 \mathrm{mg} /$ $\mathrm{kg}$ Q2wk). Of the 30 patients treated with RN168, 22 (73.3\%) developed anti-drug antibodies, of which 12 (54.5\%) were neutralizing; however, these antibodies had no apparent effects on PK parameters.

$\mathrm{PD}$ are shown in Figure 2A. RN168 doses of $3 \mathrm{mg} / \mathrm{kg} \mathrm{Q} 2 \mathrm{wk}, 6 \mathrm{mg} / \mathrm{kg} \mathrm{QW}$, and $8 \mathrm{mg} / \mathrm{kg}$ Q2wk decreased unbound IL-7 receptors ( $\mathrm{IL}_{-} 7 \mathrm{R}_{\text {free }}$ ) on $\mathrm{CD}^{+}$cells by $90 \%, 95 \%$, and $100 \%$ compared with baseline values, respectively, which was sustained until day 85 - the end of the study drug treatment. RN168 $1 \mathrm{mg} / \mathrm{kg}$ Q2wk decreased IL-7R $\mathrm{R}_{\text {free }}$ by $>90 \%$ at day 8 , but there was recovery of $\mathrm{IL}-7 \mathrm{R}_{\text {free }}$ beginning on day 15. The pattern was similar on $\mathrm{CD}^{+}$and $\mathrm{CD} 8^{+} \mathrm{T}$ cell subsets (data not shown).

Target engagement was assessed based on inhibition of ex vivo IL-7-induced phosphorylated STAT5 (pSTAT5) in CD3 ${ }^{+}$T cells (Figure 2B). RN168 doses of $3 \mathrm{mg} / \mathrm{kg}$ Q2wk, $6 \mathrm{mg} / \mathrm{kg} \mathrm{QW}$, and $8 \mathrm{mg} / \mathrm{kg}$ Q2wk exhibited near complete pSTAT5 inhibition, which was sustained over the dosing period. The inhibition of pSTAT5 was incomplete and variable at the $1 \mathrm{mg} / \mathrm{kg}$ Q2wk RN168 dose.

Effects of RN168 on immune cells. The changes in WBC counts and T, B, and NK cells are shown in Table 1, Figure 3, and Supplemental Figure 2. Total WBC and total lymphocyte counts were compared with the baseline levels throughout the study. The WBC counts declined within the first week of drug administration but remained in the normal range in all but 1 subject, who was in the $3 \mathrm{mg} / \mathrm{kg}$ group (Table 1 and Supplemental Figure 2A).

When the pooled data were analyzed with a mixed model with repeated measures and fixed effects for baseline levels, there was a significant decline in the naive $\mathrm{CD} 4^{+}$but not $\mathrm{CD} 8^{+}$naive $\mathrm{T}$ cells $(P$ $<0.01$ and $P=0.07$, respectively) (Supplemental Table 3 and Figure 3, A and B). There was also a significant decline in $\mathrm{CD}^{+}$effector and central memory $\mathrm{T}$ cell populations compared with the placebo cohort (Figure 3, C and E) (CD4 effector memory, $P=0.001$; CD4 central memory, $P=0.0007$ ). Although $\mathrm{CD}^{+}$effector and central memory cells were also decreased $(P=0.012$ and $P=0.017$, respectively), there was greater variability compared with the $\mathrm{CD} 4^{+} \mathrm{T}$ cells (Figure $3, \mathrm{D}$ and $\mathrm{F}$ ).

There was a general increase in the frequency of $\mathrm{CD} 4^{+} \mathrm{PD}-1^{+}$and $\mathrm{CD} 8^{+} \mathrm{PD}-1^{+} \mathrm{T}$ cells at day 85 , but the changes in the PD $-1^{+}$cells did not reach statistical significance (Supplemental Figure 3, mixed model with pooled data with fixed effects for baseline values, $P=0.11$ for both).

The absolute number of Tregs declined at all doses greater than $1 \mathrm{mg} / \mathrm{kg}$ (Figure 4A). The ratio of Tregs to $\mathrm{CD}^{+}$and $\mathrm{CD}^{+}$effector memory $\mathrm{T}$ cells was increased at all doses, reaching statistical significance at the $6 \mathrm{mg} / \mathrm{kg}$ Q2wk dose for $\mathrm{CD}^{+}$effector memory T cells $(P=0.04)$ (Figure 4, B and C; mixed model with repeated measures with fixed effects for baseline levels). These ratio effects were attributed to enhanced effects of RN168 on reducing effector T cells (Figure 3) compared with Tregs. The relative 


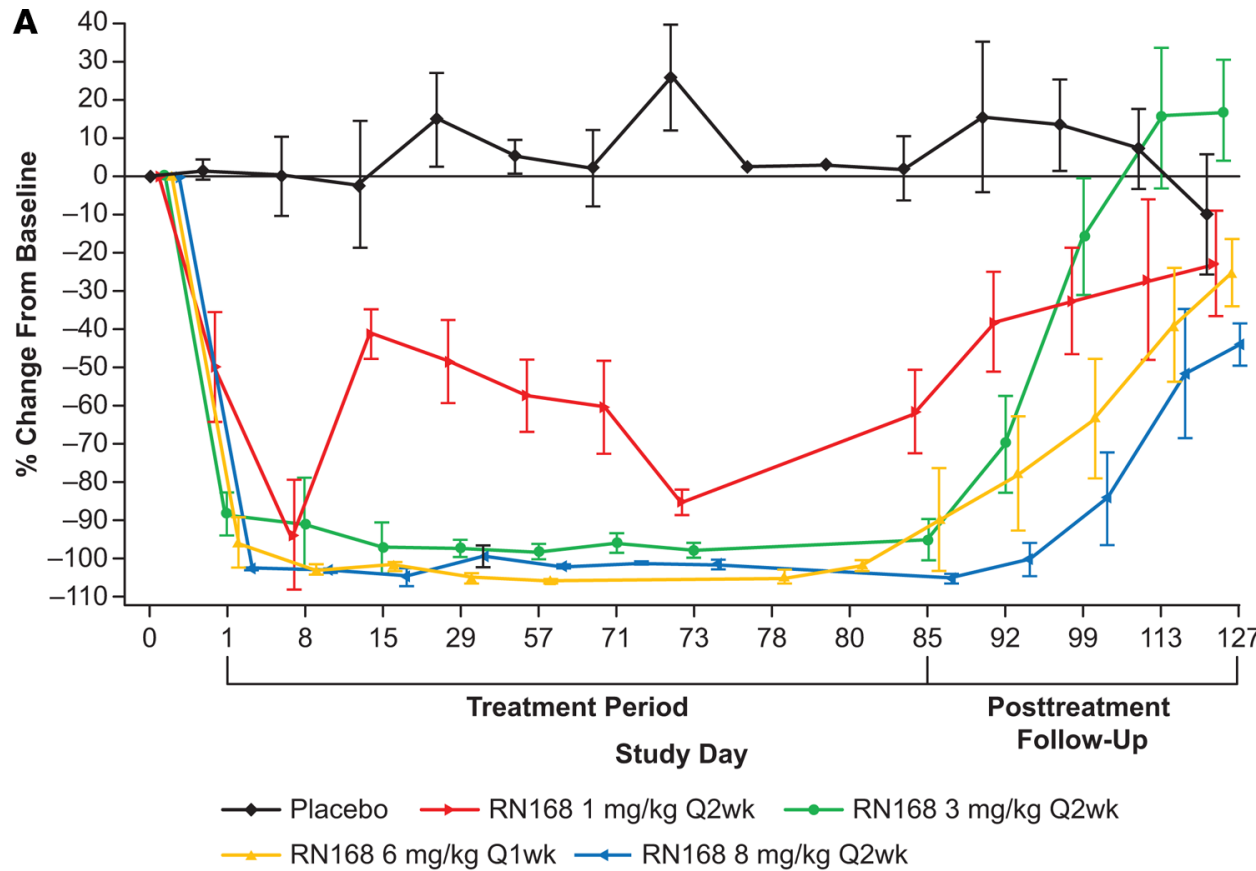

B

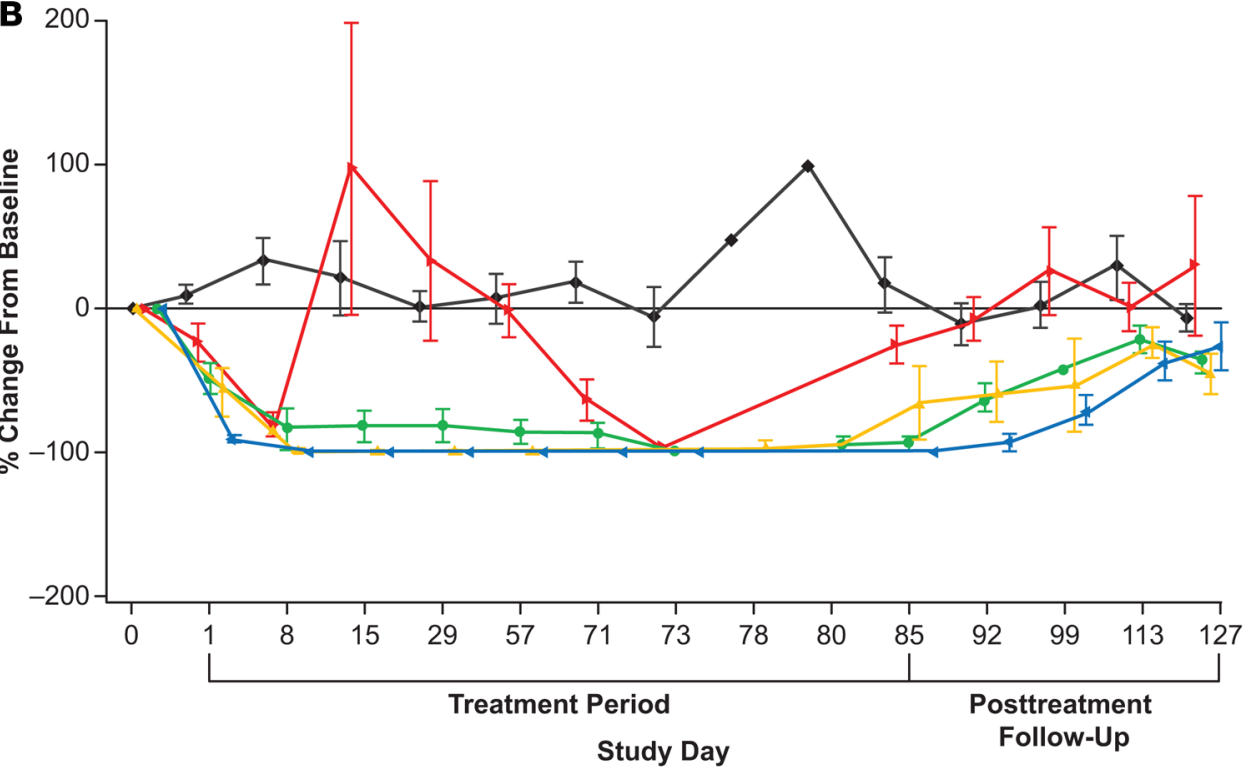

Figure 2. IL-7 receptor (IL-7R) engagement by RN168 and phosphorylation of STAT5 in $\mathrm{CD3}^{+} \mathbf{T}$ cells. (A) IL-7R on $\mathrm{CD3}^{+}$ T cells. Baseline mean $( \pm S D)$ values: placebo 1899.9 (565.6) $(n=7)$; RN168 $1 \mathrm{mg}$ 1327.7 (589.6) ( $n=8)$; RN168 3 mg 1648.3 (376.2) ( $n=9)$; RN168 6 mg 2245.8 (536.5) $(n=5)$; RN168 8 mg 2185.8 (722.8) $(n=8)$. (B) pSTAT5 in CD3 ${ }^{+}$T cells. Baseline mean $( \pm S D)$ values: placebo 3750.4 (1393.9) $(n=7)$; RN168 $1 \mathrm{mg} 3681.7$ (1665.7) ( $n=8)$; RN168 3 mg 3707.7 (1321.4) ( $n=9)$; RN168 6 mg $4066.0(722.0)(n=5) ;$ RN168 $8 \mathrm{mg}$ $3877.4(1065.5)(n=8)$.

$\longrightarrow$ Placebo $\rightarrow$ RN168 $1 \mathrm{mg} / \mathrm{kg}$ Q2wk $\multimap$ RN168 $3 \mathrm{mg} / \mathrm{kg}$ Q2wk
$\longrightarrow$ RN168 $6 \mathrm{mg} / \mathrm{kg}$ Q1wk ๘ RN168 $8 \mathrm{mg} / \mathrm{kg}$ Q2wk

number of NK cells increased at doses above $1 \mathrm{mg} / \mathrm{kg}$, but we did not observe changes in B cells (Supplemental Figure 2, D and E).

Effects of RN168 on the transcriptome of $T$ cells. Total RNA was isolated from $\mathrm{CD}^{+}$and $\mathrm{CD}^{+} \mathrm{T}$ cells magnetically separated from previously frozen peripheral blood mononuclear cells (PBMC). Whole transcriptome analysis of $\mathrm{CD}^{+}$and $\mathrm{CD}^{+}$PBMC T cells was performed using RNA sequencing (RNA-seq), and the differences in gene expression were compared between day 85 and baseline. In $\mathrm{CD} 8^{+} \mathrm{T}$ cells, there were 60 downregulated and 1 upregulated protein-coding genes that showed a statistically significant change (paired test from DEseq2, $P<0.05$ ) after correction for multiple comparisons. In the $\mathrm{CD} 8^{+}$cells, a pathway analysis identified reduced expression of genes involved in $\mathrm{T}$ cell activation $(C D 40 L)$, differentiation (LTK, $K L R B 1$ ), and effector function (IL-12, GZMK) (Figure 5, C and D). In the CD4+ $\mathrm{T}$ cells, there were 60 downregulated and 3 upregulated protein-coding genes (Figure 5, A and B). Genes downregulated in $\mathrm{CD}^{+} \mathrm{T}$ cells included those associated with $\mathrm{T}$ cell trafficking and differentiation (CCR4, CCR6, Tbet, CXCR3). There was 
Table 1. Effects of RN168 on WBC counts ${ }^{A}$

\begin{tabular}{|c|c|c|c|c|c|}
\hline Lymphocytes < $0.8 \times$ LLN & $2(25.0)$ & $2(22.2)$ & $1(12.5)$ & $2(40.0)$ & 0 \\
\hline Monocytes $>1.2 \times$ ULN & 0 & 0 & 0 & $1(20.0)$ & 0 \\
\hline Total neutrophils $>1.2 \times$ ULN & 0 & $1(11.1)$ & 0 & 0 & 0 \\
\hline
\end{tabular}

${ }^{A}$ Based on absolute counts, $10^{3} / \mathrm{mm}^{3}$, without regard for any baseline abnormality. LLN, lower limits of normal; ULN, upper limits of normal. SD in parentheses.

limited overlap in the genes downregulated in $\mathrm{CD} 4^{+}$and $\mathrm{CD} 8^{+} \mathrm{T}$ cell subsets, suggesting differential effects of RN168 on each cell population.

To further detail the PD effects of RN168 on T cell gene expression profiles, the relationship between serum RN168 exposure expressed as the average serum levels $\left(\mathrm{C}_{\text {avg }}\right)$ and gene expression change between day 85 and baseline in $C D 8^{+} \mathrm{T}$ cells was examined. Using this dose-response analysis, there were 220 genes downregulated and 80 upregulated $(P<0.01)$. Supplemental Table 4 shows a listing of the changes in the top 50 differentially expressed genes in $\mathrm{CD} 8^{+} \mathrm{T}$ cells associated with exposure to RN168. The strongest relationships were between the reduced expression of suppressor of cytokine signaling-2 (SOCS2) and Bc12 , and increased expression of cyclin dependent kinase inhibitor-2A interacting protein (CDKN2AIP), a protein that regulates DNA damage response (Figure 6A). Members of the IL-7R signaling pathway were specifically analyzed (Supplemental Table 5 and Figure 6B). The expression of IL-2RA (CD25, correlation between expression change and $\mathrm{C}_{\text {avg }}$ by linear regression, $\left.P=0.008\right)$ and the common $\gamma$ chain $(P=0.0053)$, and other transcripts associated with signaling (MAP2K2, STAT5B), showed reduced expression at higher $C_{\text {avg }}$. The $I L-7 R$ gene itself showed increased gene expression at higher $C_{\text {avg }}(C D 127, P=0.024)$ (Figure 6C).

To confirm our transcriptome findings, we analyzed the expression of 1 of the affected genes, Bcl-2, in $\mathrm{CD}^{+} \mathrm{T}$ cells by flow cytometry. The protein expression was reduced overall in both $\mathrm{CD} 4^{+}$(molecules of equivalent soluble fluorochrome; pooled RN168 vs. placebo: mixed model with pooled data with repeated measures and fixed effects for baseline values, $P=0.0014$; Figure 7A) and $\mathrm{CD}^{+}(P=0.008) \mathrm{T}$ cells (Figure 7B). The levels were reduced at day $85\left(P=0.0009\right.$ and $P=0.02$ in $\mathrm{CD} 4^{+}$and $\mathrm{CD} 8^{+} \mathrm{T}$ cells, respectively) and returned to baseline values approximately 30 days after the last dose (CD8 ${ }^{+}$not shown).

Safety. Thirty-three subjects experienced 194 all-causality treatment-emergent adverse events (TEAEs) and were generally not dose related; the highest proportion of TEAEs was in the placebo group (Table 2 and Supplemental Table 6). The most common ( $\geq 4$ subjects) treatment-related AEs across all groups were headache, hypoglycemia, fatigue, nasopharyngitis, and nausea. After receiving $8 \mathrm{mg} / \mathrm{kg}, 1$ subject experienced lymphopenia to $<500 / \mu \mathrm{L}$ that remained low for greater than 2 months after the last study treatment. One subject in the $6 \mathrm{mg} / \mathrm{kg} \mathrm{mg} / \mathrm{kg}$ dose group, negative at baseline for CMV viral DNA but positive for IgG antibody, had detectable viral DNA on day 85 ( $<137 \mathrm{IU} / \mathrm{mL}$ CMV DNA), subsequently returning to negativity by day 127 , but this subject did not have symptoms of active CMV infection. Two subjects (1 each in the 6 and $8 \mathrm{mg} / \mathrm{kg}$ dose groups) seroconverted from negative EBV IgG (viral DNA undetectable) before treatment to positive IgG antibody at day 15 and at day 85 , respectively. The subject receiving $6 \mathrm{mg} / \mathrm{kg}$ exhibited lymphadenopathy, splenomegaly, lethargy, and pharyngitis, and the other subject receiving $8 \mathrm{mg} / \mathrm{kg}$ exhibited grade 1 submandibular lymphadenopathy at days 15-57, but this resolved. In the subject with lymphadenopathy and splenomegaly, RN168 was discontinued for 4 weeks until the viral infection event resolved. Study drug was reinstated with no further incident.

RN168 was not associated with an increase compared with placebo in allergic or hypersensitivity reactions, hypoglycemic events, or clinically significant electrocardiogram (ECG) abnormalities. While 1 patient had a transient alanine aminotransferase (ALT) increase $>3 \times$ upper limits of normal (ULN), there were no cases meeting criteria for Hy's Law. Mild injection-site reactions were reported by $14.3 \%$ of the placebo group, and $12.5 \%, 11.1 \%, 25 \%$, and $60 \%$ of the RN168 $1 \mathrm{mg} / \mathrm{kg}$ Q2wk, $3 \mathrm{mg} / \mathrm{kg}$ Q2wk, $8 \mathrm{mg} / \mathrm{kg}$ Q2wk, and $6 \mathrm{mg} / \mathrm{kg}$ QW groups, respectively. 

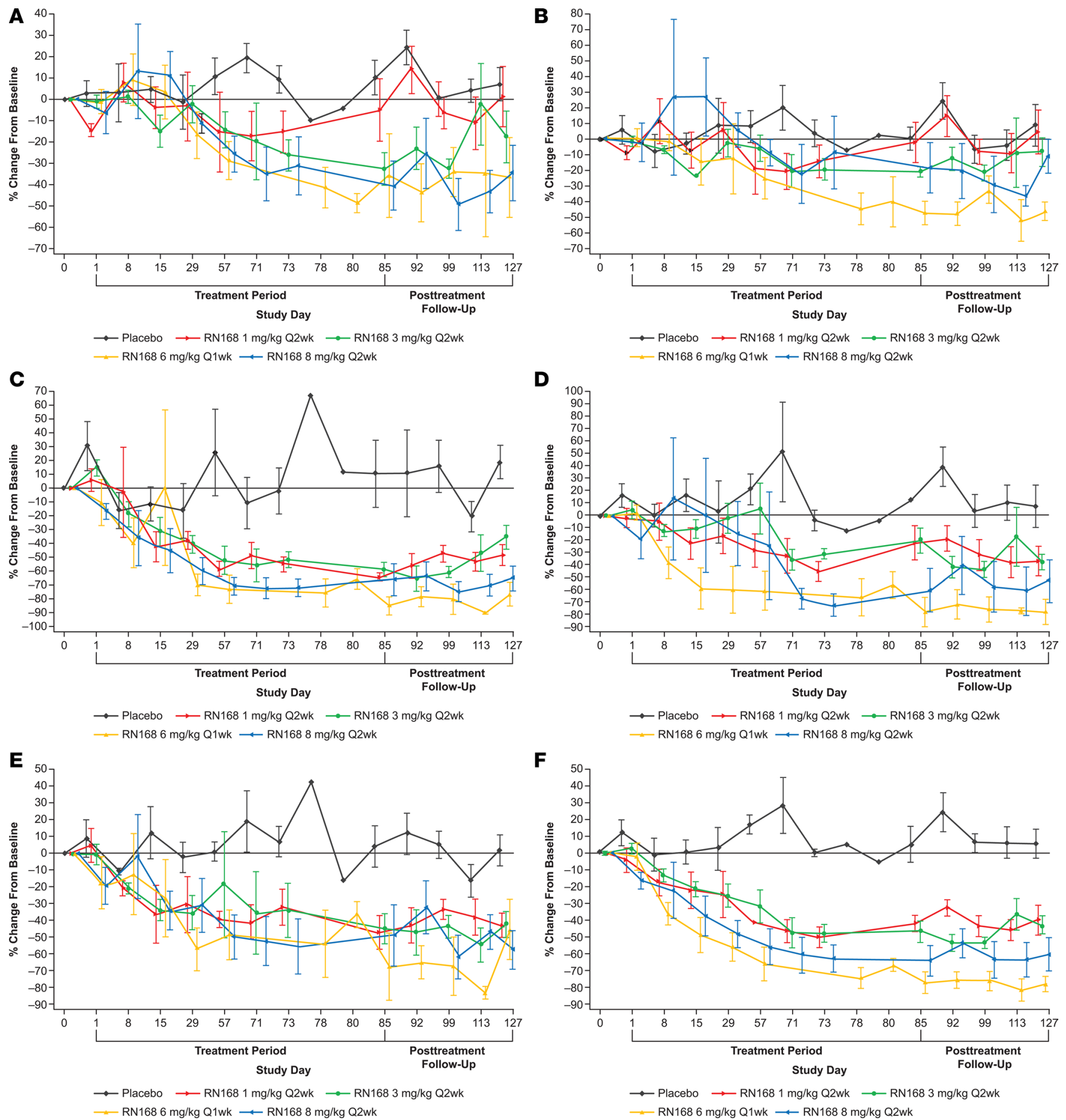

$\rightarrow$ Placebo $\rightarrow$ RN168 $1 \mathrm{mg} / \mathrm{kg}$ Q2wk $\rightarrow$ RN168 $3 \mathrm{mg} / \mathrm{kg}$ Q2wk — RN168 $6 \mathrm{mg} / \mathrm{kg}$ Q1wk — RN168 $8 \mathrm{mg} / \mathrm{kg}$ Q2wk

Figure 3. Depletion of memory T cells with RN168 analyzed by flow cytometry. (A) $C D 4^{+}$naive T cells. Baseline mean ( \pm SD) values: placebo 312.588 (127.118) ( $n=7)$; RN168 $1 \mathrm{mg} 373.576$ (139.967) ( $n=8)$; RN168 3 mg 283.811 (146.604) $(n=9) ;$ RN168 6 mg 348.374 (135.402) ( $n=5)$; RN168 8 mg 359.917 (165.903) $(n=8)$. (B) CD8+ naive T cells. Baseline mean ( \pm SD) values: placebo $224.313(142.442)(n=7)$; RN168 $1 \mathrm{mg} 217.871$ (96.265) ( $n=8)$; RN168 3 mg 1168.591 (119.241) ( $n=9$ ); RN168 6 mg 230.688 (42.754) $(n=5)$; RN168 8 mg 143.347 (73.942) ( $n=8)$. (C) CD4 ${ }^{+}$effector memory T cells. Baseline mean ( \pm SD) values: placebo 78.740 (37.003) ( $n=7)$; RN168 $1 \mathrm{mg} 61.577$ (24.059) ( $n=8)$; RN168 $3 \mathrm{mg} 51.880(24.289)(n=9) ; \mathrm{RN168} 6 \mathrm{mg}$ 104.004 (28.278) ( $n=5)$; RN168 8 mg 98.285 (57.377) ( $n=8)$. (D) CD8+ effector memory. Baseline mean ( \pm SD) values: placebo 69.043 (34.030) ( $n=$ 7); RN168 $1 \mathrm{mg} 101.506$ (39.746) ( $n=8)$; RN168 3 mg 56.524 (34.175) $(n=9) ; \operatorname{RN} 1686$ mg 107.370 (64.998) $(n=5)$; RN168 8 mg 113.887 (102.241) ( $n=$ 8). (E) CD4+ central memory T cells. Baseline mean ( \pm SD) values: placebo 259.875 (57.937) ( $n=7)$; RN168 $1 \mathrm{mg} 318.130$ (161.006) ( $n=8)$; RN168 3 mg 326.387 (138.693) ( $n=9)$; RN168 6 mg 440.594 (171.652) ( $n=5)$; RN168 8 mg 367.127 (154.881) $(n=8)$. (F) CD8 ${ }^{+}$central memory T cells. Baseline mean $( \pm$ SD) values: placebo 52.228 (12.748) $(n=7)$; RN168 $1 \mathrm{mg} 44.133$ (12.803) ( $n=8)$; RN168 $3 \mathrm{mg} 60.531(46.720)(n=9)$; RN168 $6 \mathrm{mg} 78.612(39.220)(n$ = 5); RN168 8 mg $53.712(61.200)(n=8)$. 
Table 2. Incidence of treatment-related AEs occurring in at least 2 subjects

\begin{tabular}{|c|c|c|c|c|c|}
\hline $\begin{array}{l}\text { AE, MedDRA version } 19.1 \\
\text { preferred term }\end{array}$ & $\begin{array}{c}\text { RN168 } 1 \mathrm{mg} / \mathrm{kg} \text { Q2wk } \\
(n=8)\end{array}$ & $\begin{array}{c}\text { RN168 } 3 \mathrm{mg} / \mathrm{kg} \text { Q2wk } \\
(n=9)\end{array}$ & $\begin{array}{c}\text { RN168 } 8 \mathrm{mg} / \mathrm{kg} \text { Q2wk } \\
(n=8)\end{array}$ & $\begin{array}{c}\text { RN168 } 6 \mathrm{mg} / \mathrm{kg} \text { Q1wk } \\
(n=5)\end{array}$ & Placebo $(n=7)$ \\
\hline Headache & $2(25.0)$ & $2(22.2)$ & $3(37.5)$ & 0 & 0 \\
\hline Fatigue & $1(12.5)$ & 0 & $1(12.5)$ & 0 & $2(28.6)$ \\
\hline Lymphocytes decreased & $1(12.5)$ & 0 & $1(12.5)$ & $2(40.0)$ & 0 \\
\hline Cough & $1(12.5)$ & 0 & $1(12.5)$ & $1(20.0)$ & 0 \\
\hline Diarrhea & 0 & 0 & $1(12.5)$ & $1(20.0)$ & $1(14.3)$ \\
\hline Injection site erythema & 0 & 0 & $1(12.5)$ & $1(20.0)$ & $1(14.3)$ \\
\hline Injection site pain & 0 & 0 & $1(12.5)$ & $1(20.0)$ & $1(14.3)$ \\
\hline Lymphadenopathy & $1(12.5)$ & 0 & $1(12.5)$ & $1(20.0)$ & 0 \\
\hline Injection site bruising & 0 & $1(11.1)$ & 0 & $1(20.0)$ & 0 \\
\hline Injection site pruritus & 0 & 0 & $1(12.5)$ & 0 & $1(14.3)$ \\
\hline Lethargy & 0 & $1(11.1)$ & 0 & $1(20.0)$ & 0 \\
\hline Neutrophils decreased & 0 & 0 & 0 & $1(20.0)$ & $1(14.3)$ \\
\hline Rash & $1(12.5)$ & 0 & 0 & 0 & $1(14.3)$ \\
\hline Vomiting & 0 & $1(11.1)$ & 0 & 0 & $1(14.3)$ \\
\hline
\end{tabular}

AE, adverse event; MedDRA, Medical Dictionary for Regulatory Activities; Q2wk, every other week; QW, weekly. SD in parentheses.

Clinical responses to treatment with $R N 168$. We analyzed C-peptide responses to a mixed meal test and primary recall responses to tetanus toxoid (Figure 8). There was little change in the C-peptide AUC C-peptide in either the placebo or drug-treated subjects (Figure 8A).

At the day-85 visit, 2 patients receiving placebo, 3 patients receiving $1 \mathrm{mg} / \mathrm{kg}$ Q2 $\mathrm{wk}, 3$ patients receiving 3 $\mathrm{mg} / \mathrm{kg}$ Q2wk, and 2 patients receiving $8 \mathrm{mg} / \mathrm{kg}$ Q2 $\mathrm{wk}$ had an increase in C-peptide compared with baseline; the increased level was sustained in 1 patient receiving placebo, 1 patient in the $1 \mathrm{mg} / \mathrm{kg}$, and 2 patients $3 \mathrm{mg} /$ $\mathrm{kg}$ group. We also did not detect any significant effects on hemoglobin $\mathrm{A} 1 \mathrm{C}(\mathrm{HbA} 1 \mathrm{c})$ levels or insulin use (Supplemental Figure 4, A and B).

We also determined the effects of drug treatment on recall immune responses. The study subjects received a booster dose of tetanus toxoid, and the effects of the immunization were studied on days 29 and 43. Primary recall response (at day 43) was reduced in participants who received the 2 higher doses of RN168 ( $\left.\chi^{2}=13.7, P=0.009\right)$ (Figure 8B). We did not find a direct relationship between a negative recall response and the changes in lymphocyte counts.

\section{Discussion}

The results of this phase Ib study show that, in adult subjects with T1D, blockade of IL-7R decreases memory and effector $\mathrm{T}$ cells, while largely not affecting Tregs. Specifically, we found reduced CD4 ${ }^{+}$and $\mathrm{CD}^{+} \mathrm{T}$ effector and memory cell numbers, but we found preservation of the relative proportion of Tregs. The expression of genes associated with $\mathrm{T}$ cell activation and differentiation were modulated. Protective immunity to tetanus toxoid was maintained at doses $\leq 3 \mathrm{mg} / \mathrm{kg}$ Q2wk. Our transcriptome and phenotype data suggest that $\mathrm{T}$ cell survival was reduced by starvation of IL-7, which is needed for $\mathrm{T}$ cell viability and function. This mechanism of action may be useful for treatment of some $\mathrm{T}$ cell-based autoimmune diseases in which depletion of effector and memory $\mathrm{T}$ cells is desired.

Target engagement by RN168 was confirmed by a dose-dependent decrease in binding by a competitive antibody and by decreased IL-7-induced pSTAT5 in an ex vivo assay. These decreases were observed at $1 \mathrm{mg} / \mathrm{kg}$ and reached a plateau at $3 \mathrm{mg} / \mathrm{kg}$. Reductions in pSTAT5 in T cells and lower expression of the 

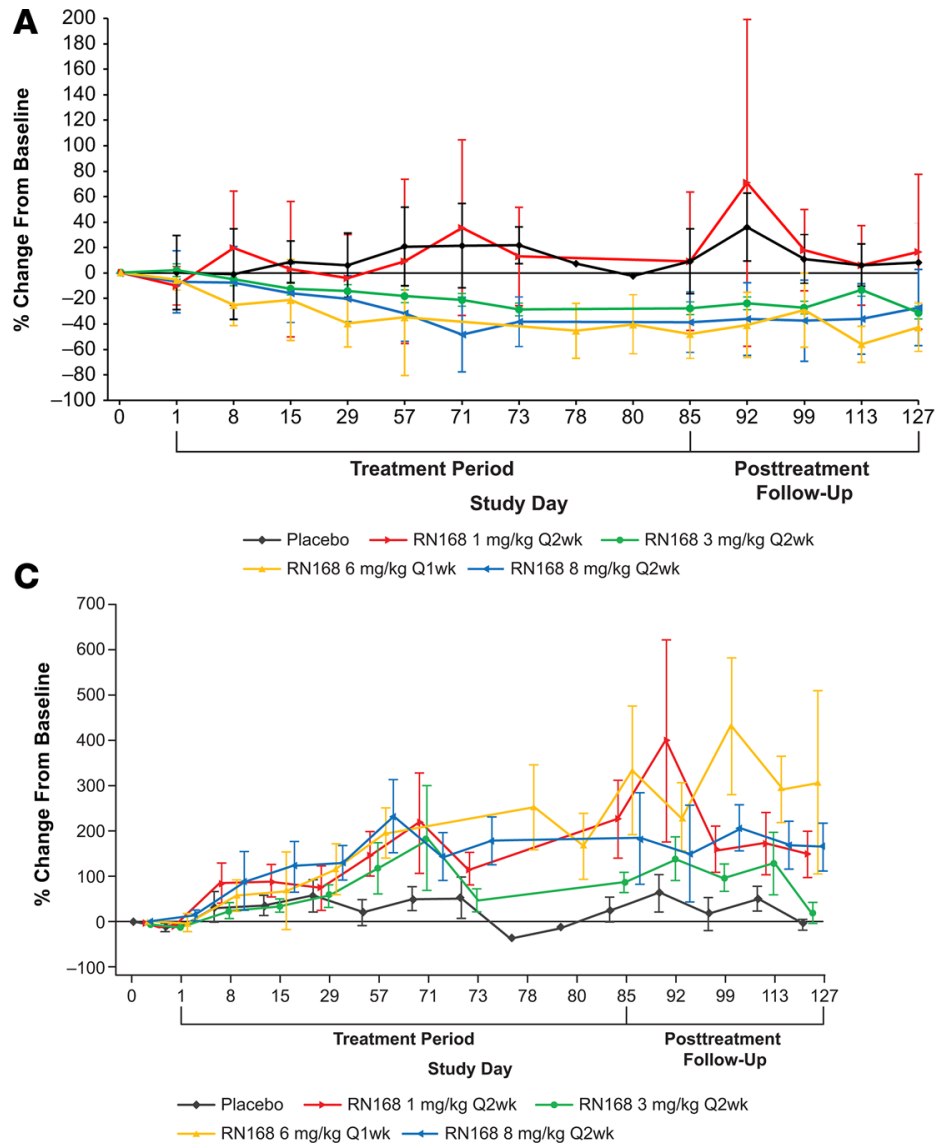

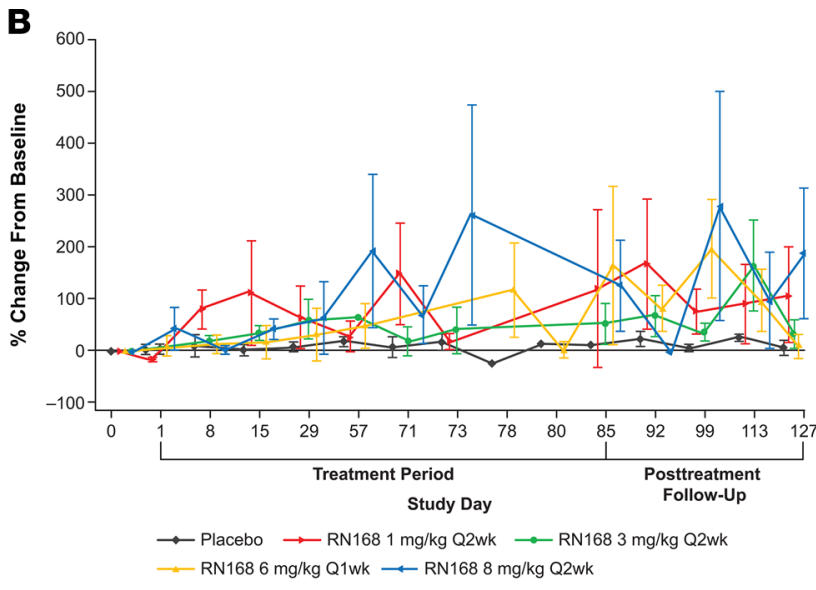

Figure 4. Effects of RN168 on $\mathrm{CD}^{+}{ }^{+} \mathrm{FoxP3}^{+}$Tregs assessed by flow cytometry. (A) Tregs. Baseline mean $( \pm S D)$ values: placebo 44.2733 (7.5852) ( $n=7)$; RN168 $1 \mathrm{mg} 45.7443$ (22.0758) $(n=$ 8); RN168 3 mg 49.8629 (15.9373) ( $n=9$ 9); RN168 6 mg 50.5640 (15.3193) $(n=5)$; RN168 $8 \mathrm{mg} 63.3043$ (31.3837) $(n=8)$. (B) Ratio of Tregs to CD4+ effector memory T cells. Baseline mean $( \pm$ SD) values: placebo 0.650 (0.248) $(n=7) ; \mathrm{RN168} 1 \mathrm{mg} 0.776$ (0.348) ( $n=8)$; RN168 $3 \mathrm{mg} 1.104(0.483)(n=9) ;$ RN168 $6 \mathrm{mg}$ $0.522(0.216)(n=5)$; RN168 $8 \mathrm{mg} 0.774(0.377)(n=8)$. (C) Ratio of Tregs to CD8 ${ }^{+}$effector memory T cells. Baseline mean $( \pm S D)$ values: placebo $0.931(0.830)(n=7)$; RN168 $1 \mathrm{mg} 0.588(0.304)$ $(n=8)$; RN168 $3 \mathrm{mg} 1.206(0.824)(n=9) ;$ RN168 $6 \mathrm{mg} 0.604$ $(0.321)(n=5)$; RN168 $8 \mathrm{mg} 0.767(0.655)(n=8)$.

anti-apoptotic protein Bcl-2 suggest inhibition of IL-7 signaling. IL-7RA blockade in NOD mice resulted in PD-1 upregulation, a change that was mimicked in our human studies, although the changes did not reach statistical significance $(10,11)$.

Overall, the safety experience was acceptable and adverse events were reversible, particularly at doses $<6 \mathrm{mg} / \mathrm{kg}$ weekly. RN168 was well tolerated, with most treatment-related AEs considered mild in grade. In addition, analysis of tetanus toxoid responses suggested that the higher doses of the RN168 interfered with the recall response to the vaccine. This outcome might be predicted as central memory $\mathrm{CD}^{+} \mathrm{T}$ cells, which provide help for the $\mathrm{B}$ cell recall response, express high levels of CD127, and were thus affected by the IL-7RA blockade.

Our transcriptome studies by RNA-seq showed that the expression of signaling molecules that are associated with $\mathrm{T}$ cell survival and anti-apoptotic protein Bcl-2 were reduced. In lieu of functional assessments, changes in the transcriptional profile of isolated $\mathrm{CD} 4^{+}$and $\mathrm{CD} 8^{+} \mathrm{T}$ cells between baseline and day 85 were interrogated by RNA-seq. We found that key activation-related genes were downregulated in $\mathrm{CD}^{+} \mathrm{T}$ cells with RN168 treatment, including LTK, CCR4, CD40 ligand, and KLRB1, rather than genes associated with exhaustion in $\mathrm{CD}^{+} \mathrm{T}$ cells $(28,29)$. We suggest that these transcriptional changes may be an overall response to the loss of IL-7-dependent survival signals. Unlike the transcriptional findings associated with low CD127 expression on $\mathrm{CD}^{+} \mathrm{T}$ cells reported by McKinney et al. (14), we also found changes in $\mathrm{CD} 4^{+} \mathrm{T}$ cells with cytokine blockade, consistent with the general importance of IL-7 generally on T cell growth and survival.

Despite the changes in effector T cells, the relative numbers of Tregs were less affected. As a result, we observed a trend for increased Treg/CD4 effector T cell ratio at the $1 \mathrm{mg} / \mathrm{kg} \mathrm{Q} 2 \mathrm{wk}, 6 \mathrm{mg} / \mathrm{kg} / \mathrm{Q} 1 \mathrm{wk}$, and 8 $\mathrm{mg} / \mathrm{kg}$ Q2wk doses. A change in this ratio has been suggested to result in improved immune regulation, but further functional studies will be needed to confirm this hypothesis (21). The increased ratio was particularly evident at the $1 \mathrm{mg} / \mathrm{kg}$ dose of RN168, which may suggest that this dose is optimal. It is important to note that the changes that are seen were in the peripheral blood, and we cannot be certain about the effects of the antibody on the relative numbers of cells in the tissues or secondary lymph structures. Most likely, the differential effects on Tregs and effector memory $\mathrm{CD} 4^{+} \mathrm{T}$ cells is explained by the relative importance of IL-7 
A

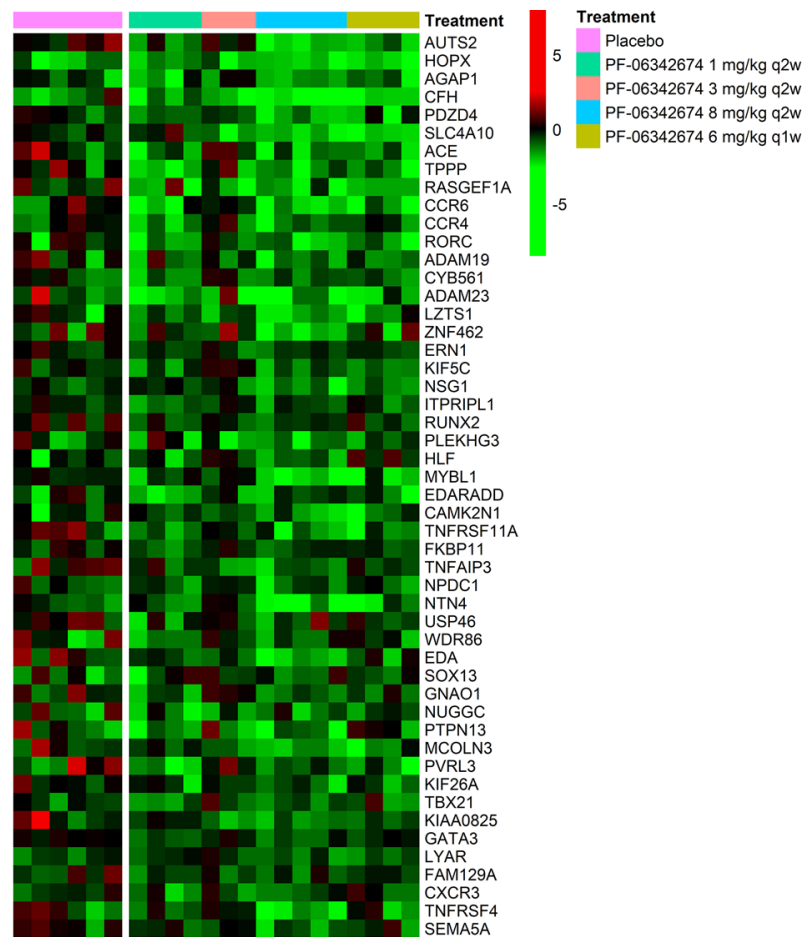

\section{C}

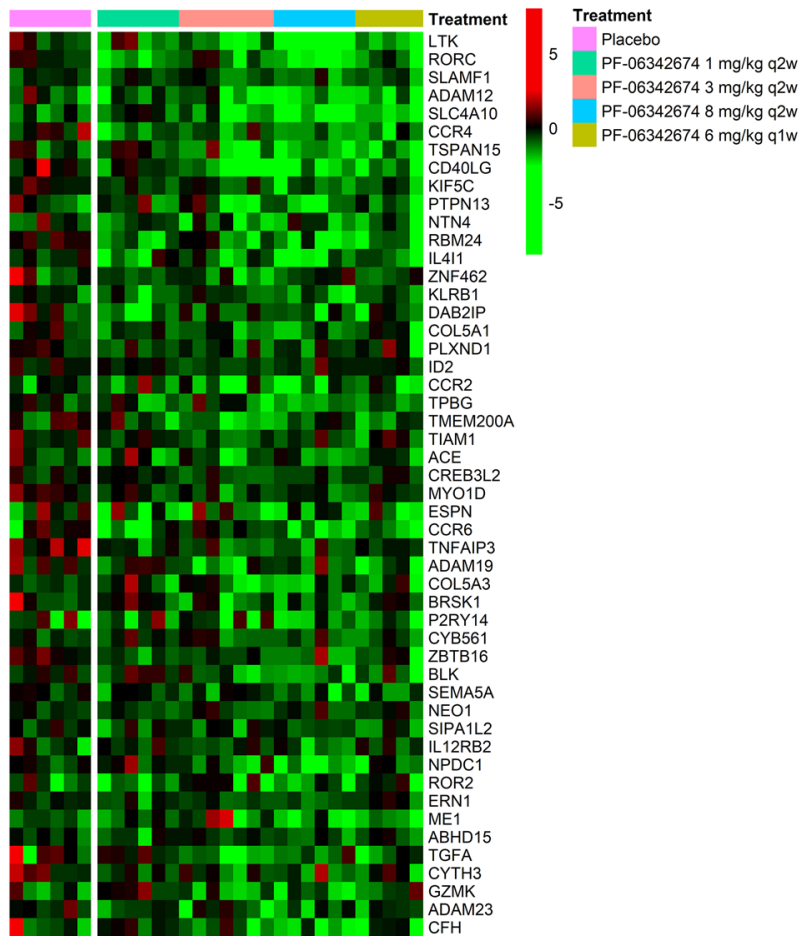

B
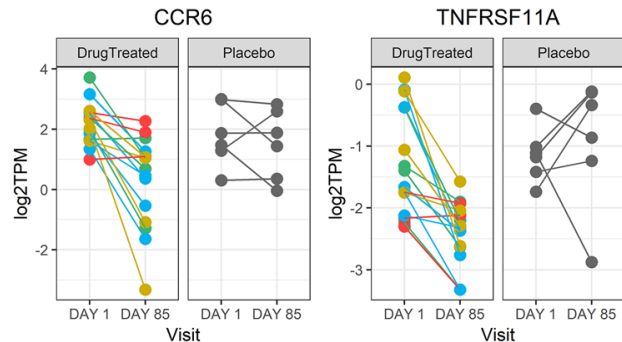

Treatment

- Placebo

- PF-06342674 1 mg/kg q2w - PF-06342674 $3 \mathrm{mg} / \mathrm{kg}$ q2W

- PF-06342674 8 mg/kg q2w

- PF-06342674 $6 \mathrm{mg} / \mathrm{kg}$ q1w

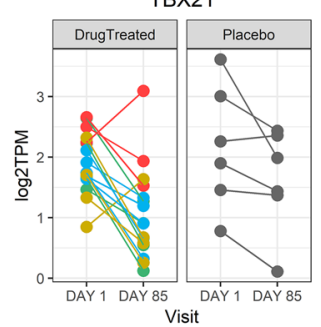

GATA3

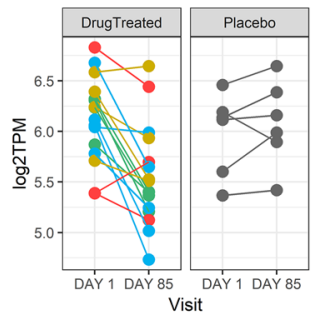

D
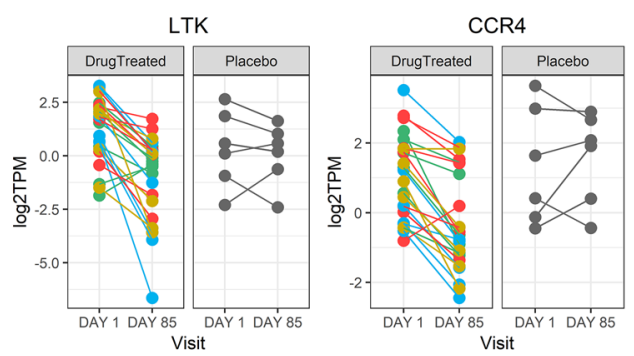

Treatment

- Placebo

- PF-06342674 $1 \mathrm{mg} / \mathrm{kg}$ q2w

- PF-06342674 3 mg/kg q2w

- PF-06342674 $8 \mathrm{mg} / \mathrm{kg}$ q2W

- PF-06342674 $6 \mathrm{mg} / \mathrm{kg} \mathrm{q} 1 \mathrm{w}$
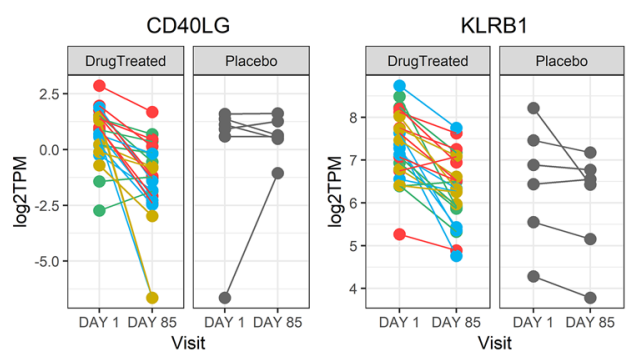

Figure 5. Gene expression changes in peripheral blood $\mathrm{CD8}^{+}$and $\mathrm{CD4} 4^{+} \mathrm{T}$ cells between day 85 and baseline in response to dosing with RN168. (A) Heatmap of gene expression change of the top 50 differential protein-coding genes in CD4+ $T$ cells. (B) Changes in expression of select immune-related genes (CCR6, RANK, Tbet, and GATA3) in CD4+ T cells. (C) Heatmap of change in expression of top 50 differentially expressed protein-coding genes in CD8 ${ }^{+} \mathrm{T}$ cells.

(D) Changes in expression of select immune-related genes (LTK, CCR4, CD4OLG, and KLRB1) in CD8 ${ }^{+} \mathrm{T}$ cells.

and IL-2 as survival factors for effector T cells and Tregs, respectively. IL-7 is critical for the development and maintenance of memory-CD $8^{+} \mathrm{T}$ cells in mice after viral infection $(3,30)$ and supports antigen-specific expansion and effector cytokine production. In addition, IL-7 can also facilitate T cell proliferation in antigen-independent mechanisms in settings such as lymphopenia, with a greater effect on $\mathrm{CD} 8^{+}$than $\mathrm{CD} 4^{+}$ 
A

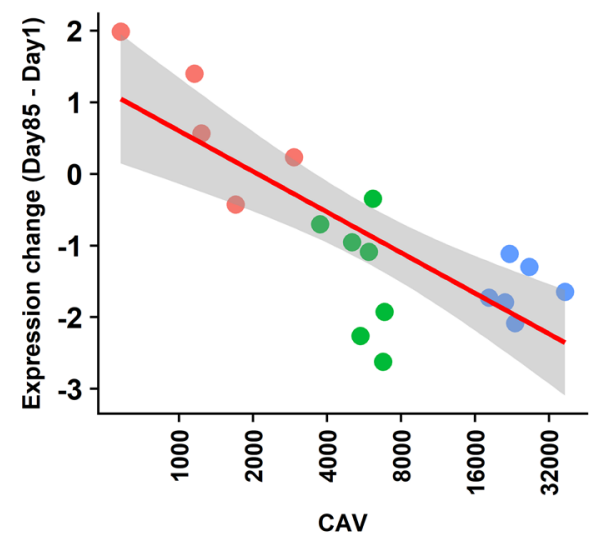

BCL2

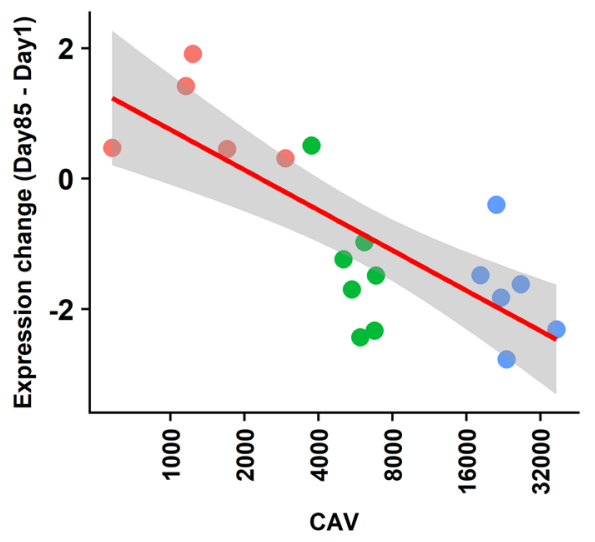

CDKN2AIP

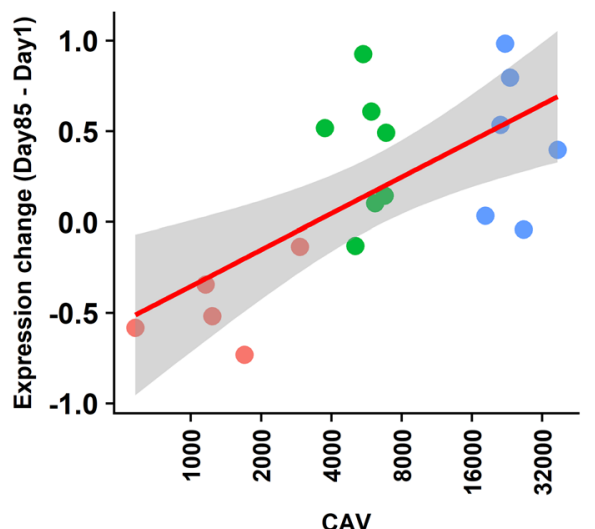

Treatment

PF-06342674 $1 \mathrm{mg} / \mathrm{kg} \mathrm{q2w}$

PF-06342674 $3 \mathrm{mg} / \mathrm{kg}$ q2w

PF-06342674 $8 \mathrm{mg} / \mathrm{kg} \mathrm{q2w}$
B

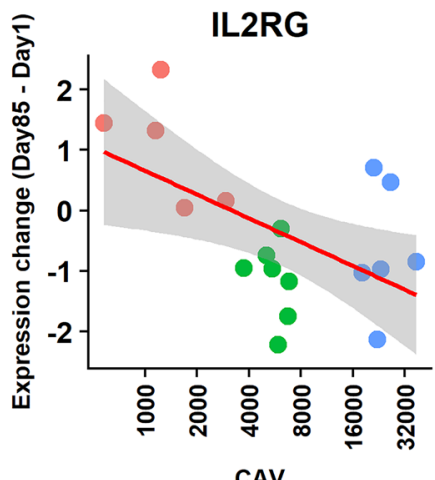

C

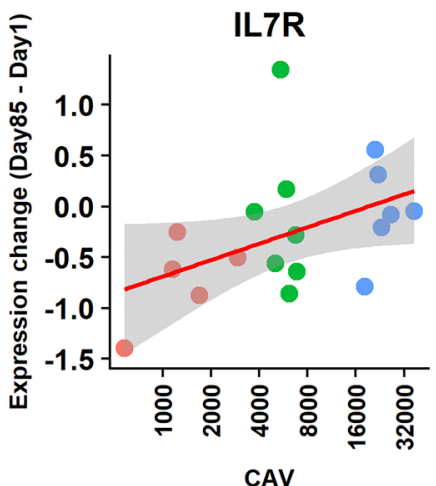

Figure 6. Dose-response analysis of RN168 average concentration ( $C_{\text {avg }}$ ) and gene expression change between day 85 and baseline in CD8 ${ }^{+}$cells. (A) Correlation of select individual genes. (B) Association of IL-2RG. (C) Association of IL-7R expression.
Treatment

- PF-06342674 $1 \mathrm{mg} / \mathrm{kg}$ q2w

- PF-06342674 $3 \mathrm{mg} / \mathrm{kg}$ q2w

PF-06342674 $8 \mathrm{mg} / \mathrm{kg}$ q2w

$\mathrm{T}$ cells (31). These findings of the Tregs/effector $\mathrm{T}$ cells are reminiscent of observations with alefacept treatment of patients with new-onset T1D and were thought to explain the long-term effects of the LFA-3 Ig treatment. The number of NK cells were not reduced and, instead, showed an increase at higher doses. However, single cell transcriptome analysis in the future will be needed to resolve these differential effects on $\mathrm{T}$ cell subpopulations. It was reassuring that we did not see a decline in C-peptide, which was associated with increased NK cell frequency with high-dose IL-2 therapy (32).

Sufficient PBMC sampling was unavailable in this study to interrogate antigen-specific T cell activity ex vivo, but our functional data show that memory responses to tetanus toxoid were unaffected, except at the 2 highest doses. Nonetheless, the reduced effector memory $\mathrm{CD} 4^{+}$and $\mathrm{CD} 8^{+} \mathrm{T}$ cells may result in reduced pathologic $\mathrm{T}$ cells that can mediate autoimmune killing of $\beta$ cells in T1D

There are limitations to our study. First, our transcriptome data were exploratory, and we did not correct for multiple comparisons when studying the relationship between gene expression change and drug exposure, since the sample size was relatively small. Additional studies with a greater number of subjects with confirmatory 

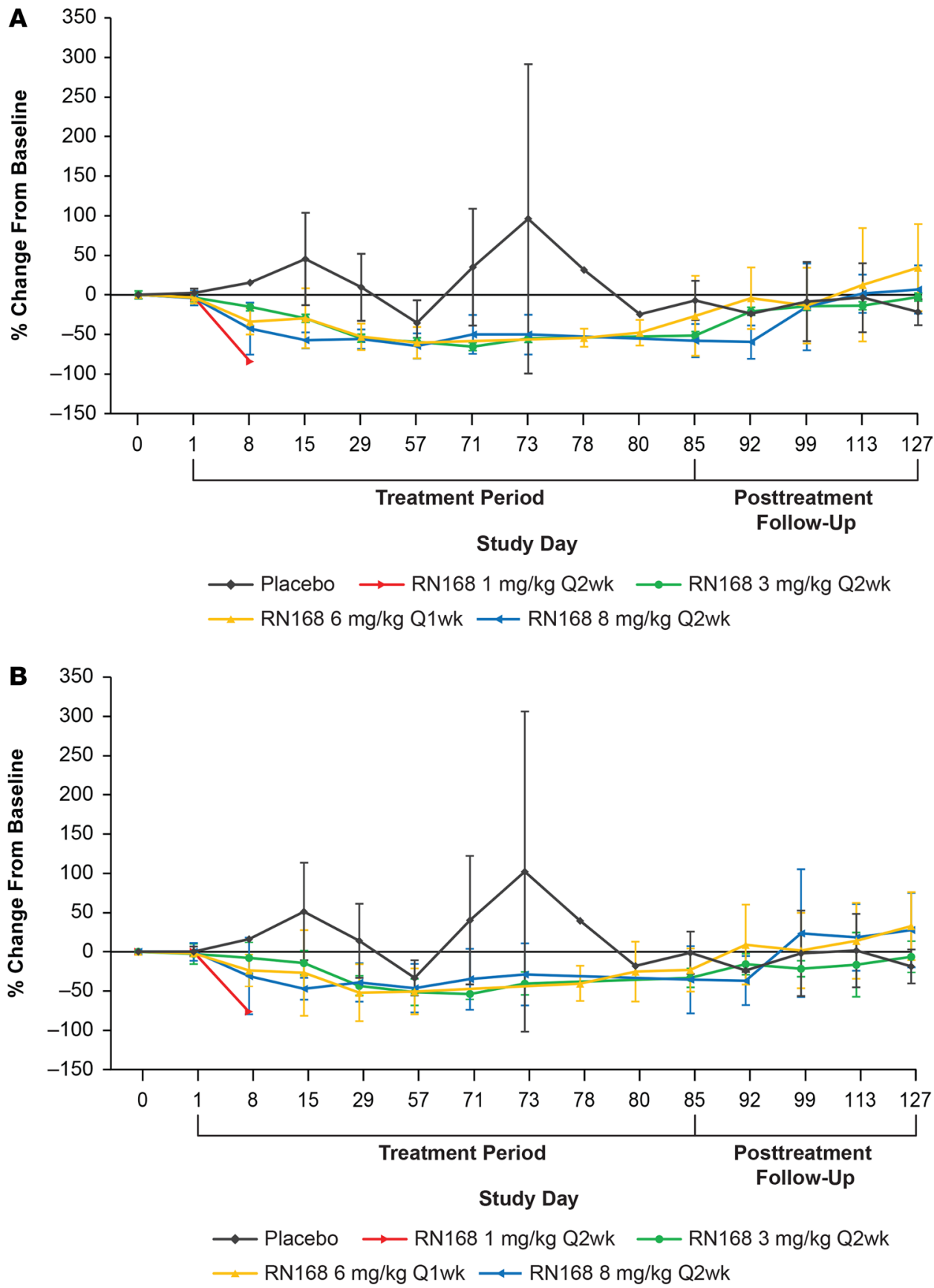

Figure 7. Percentage change from baseline in $\mathrm{Bcl}-2$ expression in $\mathrm{CD}^{+} \mathrm{T}$ cells. (A) $\mathrm{CD} 4^{+} \mathrm{BCl}-2^{+} \mathrm{T}$ cells. Baseline mean $( \pm$ SD) values: placebo 3231.750 (982.634); RN168 1 mg 5973.00 (0); RN168 3 mg 3501.000 (507.441); RN168 $6 \mathrm{mg} 3178.000$ (702.489); RN168 $8 \mathrm{mg}$ 3130.875 (1026.502). (B) CD8 ${ }^{+} \mathrm{Bcl}-2^{+} \mathrm{T}$ cells. Bcl-2 values in the RN168 $1 \mathrm{mg} / \mathrm{kg}$ Q2wk group were unavailable after day 8 due to an interruption in assay reagent availability. Baseline mean (SD) values: Placebo 3399.750 (1332.569); RN168 1 mg 3218.000(0); RN168 3 mg 3434.500 (300.684); RN168 6 mg 3217.000 (657.476); RN168 8 mg 3255.000 (1557.702). Placebo, $n=7$; RN168 $1 \mathrm{mg} /$ kgQ2wk, $n=8$; RN168 3 mg/kgQ2wk, $n=$ 9; RN168 $6 \mathrm{mg} / \mathrm{kg}$ Q1wk, $n=5$; RN168 8 $\mathrm{mg} / \mathrm{kg}$ Q2wk, $n=8$.

studies will be needed. Likewise, the analysis occurred at 1 particular time point, but there may be changes in subsets of $\mathrm{T}$ cells before and after the end of therapy that are relevant to the clinical effects. We do not have information about antigen-specific T cells, which is important both for understanding the effects on autoimmunity, but also on responses to latent viruses like EBV and CMV. Caution is needed in this regard, since - in addition to its role in survival - IL-7 and its receptor may augment cytotoxicity of CD8 ${ }^{+} \mathrm{T}$ cells, as suggested in preclinical studies of transgenesis and clinical observations of augmented viral clearance correlating with IL-7 $(33,34)$. Our study was not powered to identify clinical response of IL-7RA blockade on the progression of T1D. We saw a decline in C-peptide in only 2 of the 6 placebo-treated subjects over the study period. It may be necessary to follow a larger group of subjects for longer periods of time to determine whether there are lasting clinical effects of treatment. Finally, it is possible that the duration of diabetes at the time of enrollment (up to 2 years after diagnosis), particularly with a C-peptide threshold above $0.15 \mathrm{pmol} / \mathrm{mL}$, selected for individuals with a slow rate of loss of $\beta$ cell function. Studies in the new-onset period are more likely to identify whether there are effects of the drug on the autoimmune response at a time of maximum activity. 

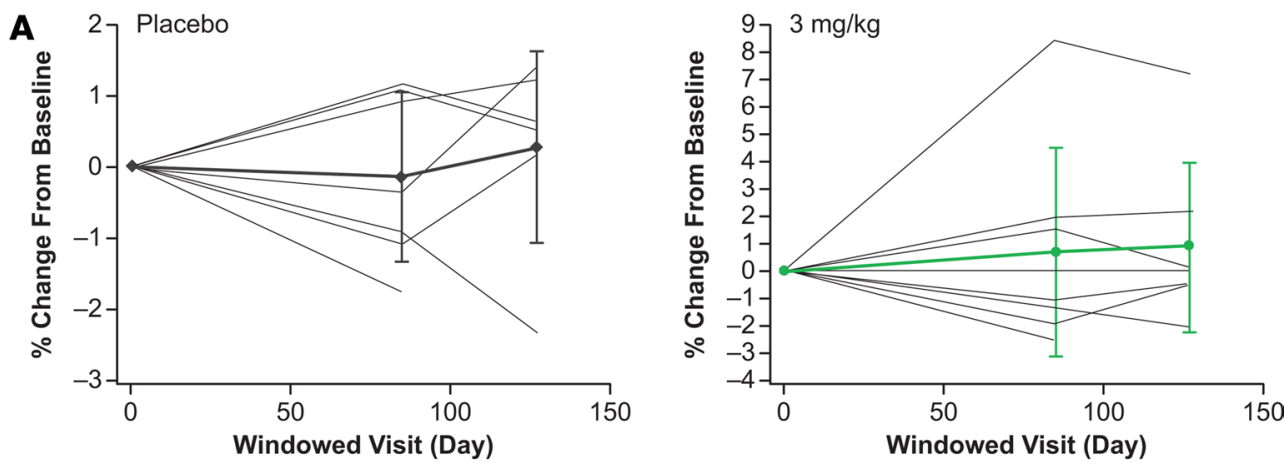

Figure 8. Effects of RN168 on clinical responses. Each line represents an individual participant. The bold, colored lines represent the mean $\pm S D$ of the dosing cohort. (A) C-peptide AUC levels. (B) Tetanus toxoid challenge, by treatment group. The number of participants in each dosing regimen are: placebo, $n=7 ; 1 \mathrm{mg} / \mathrm{kg}$ Q2wk, $n=$ 8; $3 \mathrm{mg} / \mathrm{kd} \mathrm{Q2wk,} n=9 ; 8 \mathrm{mg} / \mathrm{kg}, n=$ $8 ; 6 \mathrm{mg} / \mathrm{kg} \mathrm{QW}, n=5$.
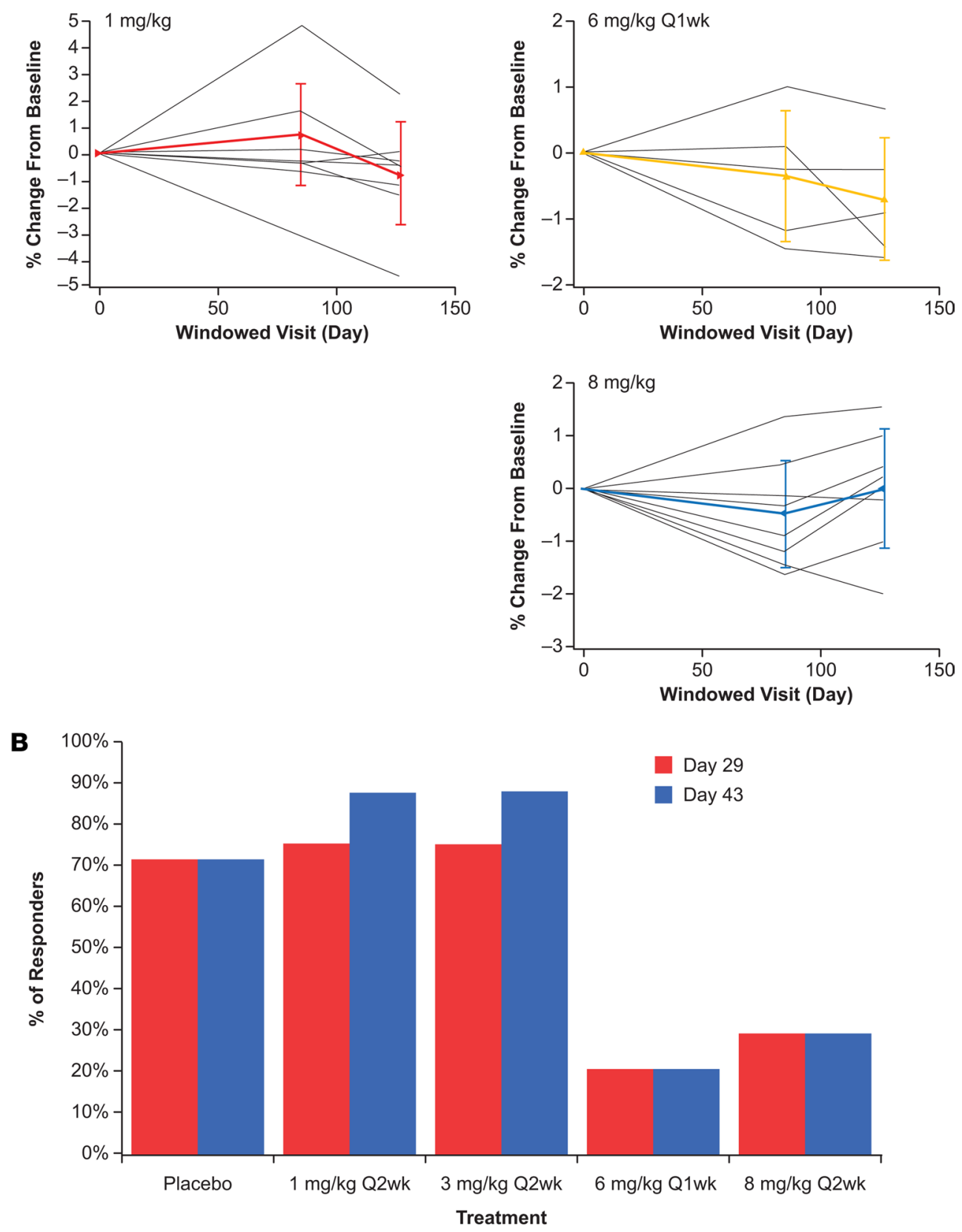

In summary, the administration of RN168 is safe and well tolerated, and it induces saturation and functional blockade of the IL-7R, resulting in a favorable immunologic profile in T1D subjects. Memory and, to a lesser extent, naive $\mathrm{T}$ cells appear to be deleted from the peripheral blood, most likely representing the deprivation of the IL-7 cytokine needed for their homeostasis. However, there is relative sparing 
of Tregs and an increase in the ratio of Treg/effector T cells. This strategy may, therefore, be optimal for treatment of unwanted chronic immune responses, such as in autoimmunity or transplant rejection, in which effector cells can be eliminated from the repertoire. Further studies to determine whether there is selectivity in these effects on $\mathrm{T}$ cell subpopulations, including effects on autoantigen-specific $\mathrm{T}$ cell clones, will be important in defining the clinical development pathway for this strategy.

\section{Methods}

Supplemental Methods are available online with this article.

Study design. This phase Ib, multicenter, double-blind (sponsor open), placebo-controlled, intracohort randomization, dose-escalating study (clinicaltrials.gov identifier: NCT02038764) was conducted between June 2014 and September 2016. The study was managed by the study sponsor (Pfizer Inc.). All study materials, including case report forms, data collection tools, and study drug, were supplied by the study sponsor. Eligible subjects were randomized to receive either RN168 or placebo in 4 dose cohorts consisting of 1, 3, and $8 \mathrm{mg} / \mathrm{kg}$ s.c. Q2wk (maximum 6 doses; cohorts $1-3$ ) or $6 \mathrm{mg} / \mathrm{kg}$ s.c. QW (maximum 12 doses; cohort 4) for 12 weeks, with follow-up for an additional 6 weeks. Ten subjects were randomized at an 8:2 active/ placebo ratio in each of the first 3 dose cohorts. Five subjects were randomized 4:1 in cohort 4 .

Study population. Generally healthy adults diagnosed with T1D within 2 years of study entry with at least 1 T1D-related autoantibody; peak stimulated C-peptide levels $\geq 0.15 \mathrm{ng} / \mathrm{mL}$ measured during a mixed meal tolerance test (MMTT); and a BMI of $18.5-32 \mathrm{~kg} / \mathrm{m}^{2}$ were enrolled. Key exclusion criteria included having at least 2 hospitalizations for diabetic ketoacidosis within 90 days of randomization, HbA1c $>9 \%$, severe hypoglycemia within 60 days of randomization, and febrile illness within 24 hours of randomization. Potential subjects were also excluded if they were using diabetes medications other than insulin, had prior or current treatment known to change immunologic status (e.g., immune modulators), or received a recent vaccination with a live virus. Complete inclusion/exclusion criteria are included in the Supplemental Methods.

PD assessments. Whole blood samples were collected for receptor occupancy (RO), pSTAT5, Bcl-2 , T cell subsets, and PD-1 $1^{+}$RN168 RO samples were taken at baseline and on days 1, 3, 8, 15, 43, and 71 (cohorts 1-3 only); 73 (cohorts $1-3$ only); 78 and 80 (cohort 4 only); and 85, 92, 99, 113, and 127. Occupancy of IL-7R by RN168 in CD3 ${ }^{+}$T cells was evaluated using a competitive antibody in a flow cytometry assay. Target engagement was also assessed by a flow cytometry assay measuring pSTAT5 (7) in whole blood exposed to IL-7 ex vivo.

Analysis of cell subsets. Absolute counts of T cell; B cell; $\mathrm{CD}_{16}{ }^{+} 56^{+} \mathrm{NK}$ cell; $\mathrm{CD} 4^{+}$and $\mathrm{CD} 8^{+}$effector memory, central memory, and naive $\mathrm{T}$ cell; and $\mathrm{CD} 4^{+}$Treg subsets were measured in fresh cells that were sent to a central lab (Covance). The Covance lab is a College of American Pathologists/Clinical Laboratory Improvement Amendments (CAP/CLIA) laboratory (CAP/CLIA certified). Naive and memory T cell phenotypes were determined on the basis of staining with CD45RO, CD45RA, and CCR7: naive, CD45RA ${ }^{+} \mathrm{CCR} 7^{+}$; effector, $\mathrm{CD} 45 \mathrm{RO}^{+} \mathrm{CCR} 7^{-}$; central memory, $\mathrm{CD} 45 \mathrm{RO}^{+} \mathrm{CCR} 7^{+}$. Tregs were identified as $\mathrm{CD}^{+} \mathrm{FoxP}^{+} \mathrm{CD} 25^{+}$. In addition, expression of Bcl- 2 and $\mathrm{PD}-1$ on $\mathrm{CD}^{+}$and $\mathrm{CD} 8^{+} \mathrm{T}$ cell subsets was measured by flow cytometry. The absolute and relative proportions of these $\mathrm{T}$ cell subsets and change from baseline were calculated.

$R N A$-seq studies. Assessments of immunophenotype included RNA-seq analysis of peripheral blood $\mathrm{CD}^{+}$and $\mathrm{CD}^{+} \mathrm{T}$ cells isolated from PBMC preparations using magnetic bead separation. Sequence alignment and gene expression quantification was performed using OmicSoft ArraySuite software, version 9.0.9.47. Transcripts per million (TPM) were generated as normalized gene expression. Subsequent analysis was performed using $\mathrm{R}$ (version 3.4.0).

$P K$ assessments. As detailed in the Supplemental Methods, blood samples for PK analyses were collected at prespecified time points through study day 127. PK parameters were calculated using noncompartmental analysis of concentration-time data, with samples below the lower limit of quantitation (i.e., $<75.0 \mathrm{ng} / \mathrm{mL}$ ) set to zero. Serum samples were also collected for analysis of soluble (s) IL-7RA and IL-7.

Disease-related and clinical parameters. The AUC of the C-peptide response to a 4-hour MMTT was calculated from studies at screening, day 85 (end of treatment), and day 127 (final follow-up). HbA1c was measured at a central laboratory, and the daily use of exogenous insulin for the 3 days prior was determined by subject logs at the time of study visits. An 8-point glucose profile at specified days and daily insulin dose were collected.

Safety outcomes included quantitation of TEAEs, treatment-related AEs (TRAEs), and serious AEs (SAEs); hypo- and hyperglycemia events; allergic or hypersensitivity reactions; drug-induced liver injury (DILI; potential DILI or Hy's law cases); ECG results; laboratory abnormalities; and anti-drug antibodies. 
Serum was collected for EBV and CMV IgG antibodies and viral DNA at baseline and on day 85 and the end of the follow-up period after RN168 administration. ELISA and quantitative PCR (qPCR) technology was used to measure antibodies and viral DNA, respectively.

To assess the effect of RN168 on primary recall response, all subjects had blood samples for anti-tetanus toxoid IgG taken on day 15, after which they received tetanus toxoid vaccine or Tdap vaccine (unless contraindicated). Anti-tetanus toxoid IgG titers were again determined on study days 29 and 43 . A positive response was noted when the anti-tetanus toxoid IgG titers were $\geq 2$ times baseline values.

Statistics. The sample size determination of this study was not based on statistical considerations in either treatment-related efficacy or safety outcomes. The planned sample size was 10 subjects per dose cohort (reduced to 5 subjects in cohort 4) to allow for a projected 8 treated subjects per dose. All subjects who received at least 1 dose were analyzed for safety. All subjects with at least 1 serum concentration of RN168 were included in the PK analysis population and were included in the PD population if they had measurements of relevant PD biomarkers.

SAS (v9) was used for the descriptive and summary statistics for laboratory values, biomarker analysis, AEs, and PK parameters. Paired 2-tailed $t$ test was used to evaluate within-treatment comparisons, and mixed effect model repeat measurement (MMRM) was used to determine significance in change from baseline values. For cellular data, percentages are presented, except for Bcl-2, in which the mean fluorescence of the indicated subset is shown. Analysis of covariance was done on selected cell subsets (dependent variables) with day 85 as a fixed time point, treatment as the independent variable, and baseline value as the covariate. Differential analysis was performed on RNA-seq data using DESeq2 (v1.18.1) (35), with a design matrix encoding patient identity as covariate for pairwise comparison between day 85 and baseline. Linear regression was performed to study the relationship between gene expression change and drug exposure while adjusting for baseline expression. The data are presented as mean or median \pm SD unless otherwise indicated.

Study approval. This study was reviewed and approved by IRBs and/or Independent Ethics Committees at 10 participating sites in the United States: University of Chicago, UCSF, Yale University, Washington University in St. Louis, University of Minnesota, University of Colorado, VA San Diego Healthcare System, Sterling IRB, Duke University Medical Center, and University of Massachusetts. Participants were not enrolled at University of Massachusetts or Duke University. The study was conducted in compliance with ethical principles from the Declaration of Helsinki and in accordance with all International Council for Harmonisation Good Clinical Practice Guidelines, as well as local regulatory requirements. Subjects provided written informed consent before any screening procedures were performed.

\section{Author contributions}

The study was designed by KCH, DS, ML, and PDG. KCH, JBM, BWB, JH, PAG, SEG, and JHP enrolled patients. MS and ML collected and assembled data. PAG, XW, SP, ML, GW, SLB, BJG, CU, TJ, and KCH were responsible for data analysis and interpretation. The RN168 study team included the listed authors, Louis H. Philipson (University of Chicago), and Antoinette Moran (University of Minnesota). All authors collaborated in the preparation of the manuscript and critically reviewed and provided revisions to the manuscript. All authors had access to the data and assume responsibility for the completeness and accuracy of the data and data analyses. All authors granted final approval of the manuscript for submission.

\section{Acknowledgments}

The authors thank the study subjects and all of those at the study sites who participated in the investigation. Editorial support was provided by Lauren Cerruto and Michael D. Morren of Peloton Advantage, an OPEN Health Company, and was funded by Pfizer Inc. This study was sponsored by Pfizer Inc. See Supplemental Acknowledgments for consortium details.

Address correspondence to: Kevan C. Herold, Immunology and Internal Medicine, Yale University, 300 George Street, 353E, New Haven, Connecticut 06520, USA. Phone: 203.785.6507; Email: Kevan.herold@yale.edu.

SLB's present address is: Parker Institute of Cancer Immunotherapy, San Francisco, California, USA.

XW, SP, and BJG's present address is: Lyell Immunopharma, South San Francisco, California, USA. 
ML's present address is: DNAtrix Therapeutics, San Diego, California, USA.

PDG's present address is: Calibr, a division of Scripps Research, La Jolla, California, USA.

1. Jacobs SR, Michalek RD, Rathmell JC. IL-7 is essential for homeostatic control of T cell metabolism in vivo. J Immunol. 2010;184(7):3461-3469.

2. Kondrack RM, Harbertson J, Tan JT, McBreen ME, Surh CD, Bradley LM. Interleukin 7 regulates the survival and generation of memory CD4 cells. J Exp Med. 2003;198(12):1797-1806

3. Kieper WC, et al. Overexpression of interleukin (IL)-7 leads to IL-15-independent generation of memory phenotype CD8+ T cells. J Exp Med. 2002;195(12):1533-1539.

4. Sercan Alp Ö, et al. Memory CD8(+) T cells colocalize with IL-7(+) stromal cells in bone marrow and rest in terms of proliferation and transcription. Eur J Immunol. 2015;45(4):975-987.

5. Yamaki S, et al. OX40 and IL-7 play synergistic roles in the homeostatic proliferation of effector memory CD $4^{+}$T cells. Eur $J$ Immunol. 2014;44(10):3015-3025.

6. Cui G, et al. IL-7-Induced Glycerol Transport and TAG Synthesis Promotes Memory CD8+ T Cell Longevity. Cell. 2015;161(4):750-761.

7. Carrette F, Surh CD. IL-7 signaling and CD127 receptor regulation in the control of T cell homeostasis. Semin Immunol. 2012;24(3):209-217.

8. Crawley AM, et al. Jak/STAT and PI3K signaling pathways have both common and distinct roles in IL-7-mediated activities in human CD8+ T cells. J Leukoc Biol. 2014;95(1):117-127.

9. Hammerbeck CD, Mescher MF. Antigen controls IL-7R alpha expression levels on CD8 T cells during full activation or tolerance induction. J Immunol. 2008;180(4):2107-2116.

10. Lee LF, et al. Anti-IL-7 receptor- $\alpha$ reverses established type 1 diabetes in nonobese diabetic mice by modulating effector T-cell function. Proc Natl Acad Sci USA. 2012;109(31):12674-12679.

11. Penaranda C, et al. IL-7 receptor blockade reverses autoimmune diabetes by promoting inhibition of effector/memory $\mathrm{T}$ cells Proc Natl Acad Sci USA. 2012;109(31):12668-12673.

12. Lang KS, et al. Toll-like receptor engagement converts T-cell autoreactivity into overt autoimmune disease. Nat Med. 2005;11(2):138-145.

13. Yang ZZ, et al. Expression of LAG-3 defines exhaustion of intratumoral PD-1 ${ }^{+} \mathrm{T}$ cells and correlates with poor outcome in follicular lymphoma. Oncotarget. 2017;8(37):61425-61439.

14. McKinney EF, Lee JC, Jayne DR, Lyons PA, Smith KG. T-cell exhaustion, co-stimulation and clinical outcome in autoimmunity and infection. Nature. 2015;523(7562):612-616.

15. Durward-Diioia M, Harms J, Khan M, Hall C, Smith JA, Splitter GA. CD8+ T cell exhaustion, suppressed gamma interferon production, and delayed memory response induced by chronic Brucella melitensis infection. Infect Immun. 2015;83(12):4759-4771

16. Xing Y, Hogquist KA. T-cell tolerance: central and peripheral. Cold Spring Harb Perspect Biol. 2012;4(6):a006957.

17. Hamilton-Williams EE, Bergot AS, Reeves PL, Steptoe RJ. Maintenance of peripheral tolerance to islet antigens. $J$ Autoimmun. 2016;72:118-125

18. Galarza-Muñoz G, et al. Human Epistatic Interaction Controls IL7R Splicing and Increases Multiple Sclerosis Risk. Cell. 2017;169(1):72-84.e13.

19. Parish IA, et al. The molecular signature of CD8+ T cells undergoing deletional tolerance. Blood. 2009;113(19):4575-4585.

20. Vazquez-Mateo C, Collins J, Fleury M, Dooms H. Broad induction of immunoregulatory mechanisms after a short course of anti-IL-7R $\alpha$ antibodies in NOD mice. BMC Immunol. 2017;18(1):18

21. Rigby MR, et al. Alefacept provides sustained clinical and immunological effects in new-onset type 1 diabetes patients. J Clin Invest. 2015;125(8):3285-3296.

22. Herold KC, et al. Teplizumab (anti-CD3 mAb) treatment preserves C-peptide responses in patients with new-onset type 1 diabetes in a randomized controlled trial: metabolic and immunologic features at baseline identify a subgroup of responders. Diabetes. 2013;62(11):3766-3774

23. Herold KC, et al. Teplizumab treatment may improve C-peptide responses in participants with type 1 diabetes after the new-onset period: a randomised controlled trial. Diabetologia. 2013;56(2):391-400

24. Long SA, et al. Partial exhaustion of CD8 T cells and clinical response to teplizumab in new-onset type 1 diabetes. Sci Immunol 2016;1(5):eaai7793

25. Tooley JE, et al. Changes in T-cell subsets identify responders to FcR-nonbinding anti-CD3 mAb (teplizumab) in patients with type 1 diabetes. Eur J Immunol. 2016;46(1):230-241

26. Calzascia T, et al. CD4 T cells, lymphopenia, and IL-7 in a multistep pathway to autoimmunity. Proc Natl Acad Sci USA 2008;105(8):2999-3004

27. Monti P, Bonifacio E. Interleukin-7 and type 1 diabetes. Curr Diab Rep. 2014;14(9):518.

28. Wherry EJ, et al. Molecular signature of CD8+ T cell exhaustion during chronic viral infection. Immunity. 2007;27(4):670-684.

29. McKinney EF, et al. A CD8+ T cell transcription signature predicts prognosis in autoimmune disease. Nat Med. 2010;16(5):586-591

30. Schluns KS, Kieper WC, Jameson SC, Lefrançois L. Interleukin-7 mediates the homeostasis of naïve and memory CD8 T cells in vivo. Nat Immunol. 2000;1(5):426-432.

31. Cho JH, Kim HO, Surh CD, Sprent J. T cell receptor-dependent regulation of lipid rafts controls naive CD8+ T cell homeostasis. Immunity. 2010;32(2):214-226.

32. Long SA, et al. Rapamycin/IL-2 combination therapy in patients with type 1 diabetes augments Tregs yet transiently impairs $\beta$-cell function. Diabetes. 2012;61(9):2340-2348

33. Peng Y. Forced expression of IL-7R promotes CD8 T cell cytotoxicity to self antigen. PLoS ONE. 2017;12(12):e0188112.

34. Hou H, Kang Y, Zeng Y, Li Y, Shang J. Interleukin-7 augments CD8 ${ }^{+}$T cells function and promotes viral clearance in chronic 
hepatitis C virus infection. Cytokine. 2018;102:26-33.

35. Love MI, Huber W, Anders S. Moderated estimation of fold change and dispersion for RNA-seq data with DESeq2. Genome Biol. 2014;15(12):550. 